\title{
Corrigendum
}

Genes \& Development 29: 803-816 (2015)

\section{Corrigendum: Myc and SAGA rewire an alternative splicing network during early somatic cell reprogramming}

Calley L. Hirsch, Zeynep Coban Akdemir, Li Wang, Gowtham Jayakumaran, Dan Trcka, Alexander Weiss, J. Javier Hernandez, Qun Pan, Hong Han, Xueping Xu, Zheng Xia, Andrew P. Salinger, Marenda Wilson, Frederick Vizeacoumar, Alessandro Datti, Wei Li, Austin J. Cooney, Michelle C. Barton, Benjamin J. Blencowe, Jeffrey L. Wrana, and Sharon Y.R. Dent

Due to an error during our analysis for the above-mentioned article, Supplemental Table S4 contains mistakes in sheets 12 and 13. In sheet 12, genes up-regulated and down-regulated by Myc in mouse embryonic fibroblasts (MEFs) were mistakenly included in the list of genes directly down-regulated by Myc during reprogramming, therefore also affecting the functional analysis in sheet 13. A revised version of Supplemental Table S4 (Revised_Supplemental_Table_S4.xlsx) has been posted online. This error does not affect any of the conclusions in the article.

The authors regret any confusion that may have been caused by this error.

doi: $10.1101 / \operatorname{gad} .266601 .115$ 


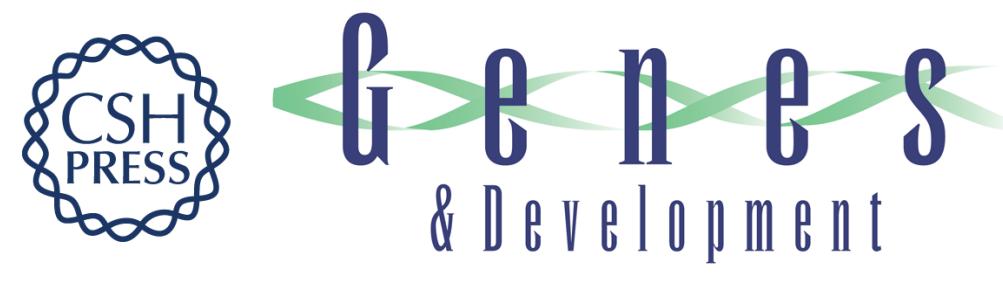

\section{Corrigendum: Myc and SAGA rewire an alternative splicing network during early somatic cell reprogramming}

Calley L. Hirsch, Zeynep Coban Akdemir, Li Wang, et al.

Genes Dev. 2015, 29:

Access the most recent version at doi:10.1101/gad.266601.115
Related Content Myc and SAGA rewire an alternative splicing network during early somatic cell reprogramming
Calley L. Hirsch, Zeynep Coban Akdemir, Li Wang, et al.
Genes Dev. April , 2015 29: 803-816

\section{License}

Email Alerting Receive free email alerts when new articles cite this article - sign up in the box at the top Service right corner of the article or click here.

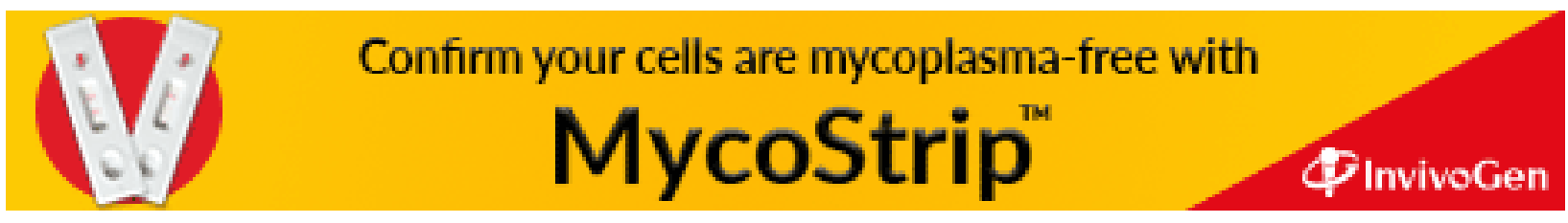

